\title{
Natural history of fibrocellular epiretinal membranes: a quantitative, autoradiographic, and immunohistochemical study
}

\author{
P S HISCOTT, ${ }^{2}$ I GRIERSON,' AND D MCLEOD
}

From the ' Department of Pathology, Institute of Ophthalmology, London, and the ${ }^{2}$ Surgical Vitreoretinal Unit, Moorfields Eye Hospital, London

SUMMARY Quantitative, autoradiographic, or immunohistochemical light microscopy was conducted on 85 surgically excised epiretinal membranes to investigate the activities of component cells and the natural history of the extraretinal scars. Membranes of less than four months' clinical duration ('early' membranes) contained significantly more cells than 'late' membranes, while collagen was more abundant in the older specimens. No correlation was established between membrane opacification and either the cellularity or the collagen content of the membranes. Epiretinal membranes had some features in common with healing skin wounds, but the activities of cells in the epiretinal membranes were relatively protracted and disordered. Fibronectin was found to be a significant component of epiretinal membranes and therefore represents a target at which pharmacological intervention could be aimed.

Contractile epiretinal membranes (ERMs) produce tangential traction on the underlying retina, with consequent inner retinal striation or full-thickness folding as seen in macular pucker and massive periretinal proliferation (MPP). Because ERMs contain fibroblast-like cells and collagen' they have been likened to the scars of healing wounds elsewhere in the body. ${ }^{2}$ Healing wounds are noted for early migration and proliferation of cells ${ }^{3}$ and production of extracellular materials, including the glycoprotein fibronectin (FN). ${ }^{+5}$ Fibroblasts cause wound contraction by virtue of their intracytoplasmic contractile filaments, including actin, ${ }^{67}$ and they also synthesise collagen to produce a fibrous scar. ${ }^{\times 9}$

Some of the maturation processes documented in healing wounds have been described in experimental models of ERM formation, but most studies of human ERMs have been orientated towards determining the origins of the cells within the ERMs. Consequently there is little information concerning the natural history of ERMs in man and the behaviour of contributing cells at each stage of membrane development. Furthermore, apart from

Correspondence to Dr I Grierson, Department of Pathology, Institute of Ophthalmology, 17-25 Cayton Strect, London EC1V 9AT. ultrastructural descriptions of microfilaments $\mathrm{s}^{10-13}$ and limited histochemical studies ${ }^{1+16}$ we know very little about actin within epiretinal cells; equally, the production and distribution of FN in ERMs have not been reported. We have therefore undertaken a detailed study of a large number of ERMs removed during closed microsurgery for macular pucker and MPP including (1) thymidine autoradiography and cell quantitation in order to provide data on the proliferative capacity and fate of cells in ERMs, (2) autoradiographic investigations of proline and glucosamine uptake in order to determine the synthetic capabilities of cells in ERMs, and (3) an immunohistochemical study of the distribution of actin and FN in ERMs with special reference to their association with specific cell types.

\section{Material and methods}

Eighty-five ERM specimens were obtained during closed microsurgery for macular pucker ( 50 eyes) or MPP (35 eyes). Aetiological associations, an estimate of clinical duration (based on the history of visual distortion, retinal detachment, etc.) and the biomicroscopic appearance of each ERM were recorded. The ERMs were arbitrarily grouped into those of less than four months' duration (early 
ERMs) and those of over four months' duration (late ERMs). Where the clinical duration of an ERM could not be estimated with any degree of accuracy, the specimen was discarded from the study.

\section{LIGHT MICROSCOPY AND CELL COUNTING}

Forty-five ERMs (21 early and 24 late) were fixed in $3 \%$ buffered glutaraldehyde, postfixed in $1 \%$ osmium tetroxide, dehydrated in graded alcohol, and embedded in Araldite. Three $1 \mu \mathrm{m}$ thick sections were obtained from each plastic embedded membrane. Intervals of $10 \mu \mathrm{m}$ were left between each section to avoid individual cell nuclei being counted twice. After toluidine blue staining the total number of cell nuclei and the number of inflammatory cell nuclei (including macrophages, polymorphonuclear leucocytes, and lymphocytes) were counted under an oil immersion lens in each section. The assessments were made by two observers (PSH and IG) independently and subsequently averaged (intra- and interobserver error $10 \%$ ). The area of each section was assessed by means of a photographic image projected on to a 'random-dot' grid, and a cumulative value of total and inflammatory cell nuclei per unit area was derived from the three sections. For statistical comparisons between early and late ERMs Student's $t$ test and the Mann-Whitney U test were adopted.

In addition the proportion of cells showing features of degeneration or necrosis, such as excessive lipid accumulation in the cytoplasm or loss of nuclear staining (karyolysis), was assessed for each ERM. Finally the proportion of collagen in each ERM was judged as follows: minimal collagen + , moderate collagen ++ , and abundant collagen +++ . Further, the arrangement of the collagen (that is, whether the fibres formed a disorganised network or were arranged in bundles) was noted.

\section{CLINICAL GRADING}

Great difficulty was experienced in grading the degree of opacification of ERMs, not least because of the wide variation in contour, extent, and thickness of the contracted membranes and potential confusion with opacification of the underlying retina, whether due to axoplasmic stasis in the inner retina or oedema of the outer retina. This latter problem was so dominant in MPP cases that we elected to confine our clinicopathological correlation to those cases of macular pucker in which there was good photographic documentation ( 23 cases). One of us (DMcL) independently ranked the epimacular membranes (from the most transparent to the most opaque) according to the predominant degree of obscuration of the blood columns in the underlying retinal vasculature. This serial grading was then compared with the total cell density and also with a similar serial grading of collagen content (from the least to the most abundant) in these 23 biopsied epimacular membrane specimens. The results were subjected to statistical analysis by the SpearmanRank correlation matrix.

\section{AUTORADIOGRAPHY}

After surgical removal 26 ERM specimens were immediately transported to the laboratory at $4^{\circ} \mathrm{C}$ in medium 199 (Wellcome, Beckenham, Kent). The tissue was incubated at $37^{\circ} \mathrm{C}$ for 24 hours in a Leighton tube incorporating $1 \mathrm{ml}$ of medium 199 enriched with $10 \%$ fetal calf serum and glutamine. The organ culture media contained one of the following radiolabelled substrates:

(1) $30 \mu \mathrm{Ci}$ of methyl- ${ }^{3} \mathrm{H}$ thymidine (specific activity 26.0 ) as a marker for cells undergoing DNA synthesis (4 early and 10 late ERMs); (2) $100 \mu \mathrm{Ci}$ of methyl- ${ }^{3} \mathrm{H}$ proline (specific activity $21 \cdot 0$ ) to indicate cells producing proteins including collagen (4 early and 3 late ERMs); or (3) $30 \mu \mathrm{Ci}$ of $\mathrm{D}-6{ }^{3} \mathrm{H}$ glucosamine hydrochloride (specific activity $34 \cdot 6$ ) to label cells synthesising glycosaminoglycans, proteoglycans, and glycoproteins, ${ }^{17}$ including fibronectin (3 early and 2 late ERMs). All radiochemicals were supplied by Amersham International PLC, Amersham, Buckinghamshire, England.

The ERMs were subsequently fixed and embedded in Araldite as described above. Sections $1 \mu \mathrm{m}$ thick were placed on gelatin covered subslides, coated with K5 nuclear emulsion (Ilford, Mobberly, Cheshire), and kept at $4^{\circ} \mathrm{C}$. After being developed with D-19 developer (Kodak, Hemel Hempstead, Hertfordshire) the sections were counterstained with toluidine blue; at least 12 sections per membrane were studied. The incorporation of label was judged as follows: background - , minimal + , moderate ++ , and avid +++ .

\section{IMMUNOHISTOCHEMISTRY FOR ACTIN AND} FIBRONECTIN

Fourteen specimens ( 7 early ERMs and 7 late ERMs) were investigated immunohistochemically by means of antiactin and anti-FN immunofluorescence or immunoperoxidase staining as previously described. ${ }^{1 \times-211}$ The distribution and intensity of actin and FN immunostaining were noted. For both, the staining intensity was graded as follows: background -; weak + ; moderate ++ , and intense +++ . 'Intense' corresponded for actin to the staining seen in extraocular muscle or, for FN, to the reaction associated with five-day rabbit skin wounds.

IMMUNOHISTOCHEMICAL CELL-TYPING

With $7 \mu \mathrm{m}$ wax or $10 \mu \mathrm{m}$ frozen serial sections, antibodies to cytoskeletal proteins identified aggre- 
Fig. 1 Sections 1 mm thick stained with toluidine blue. (a) Early ERM. Hypercellular membrane in which collagen is sparse. (b) Late ERM. Abundant collagen with bundle formation. Only a few cells are present, and several of these show lipid accumulation in the cytoplasm (arrows).

(c) Epimacular membrane associated with pars planitis. Although the ERM appears to be hypercellular, the majority of the cells are inflammatory cells, including lymphocytes and monocytes. $(\times 560)$.
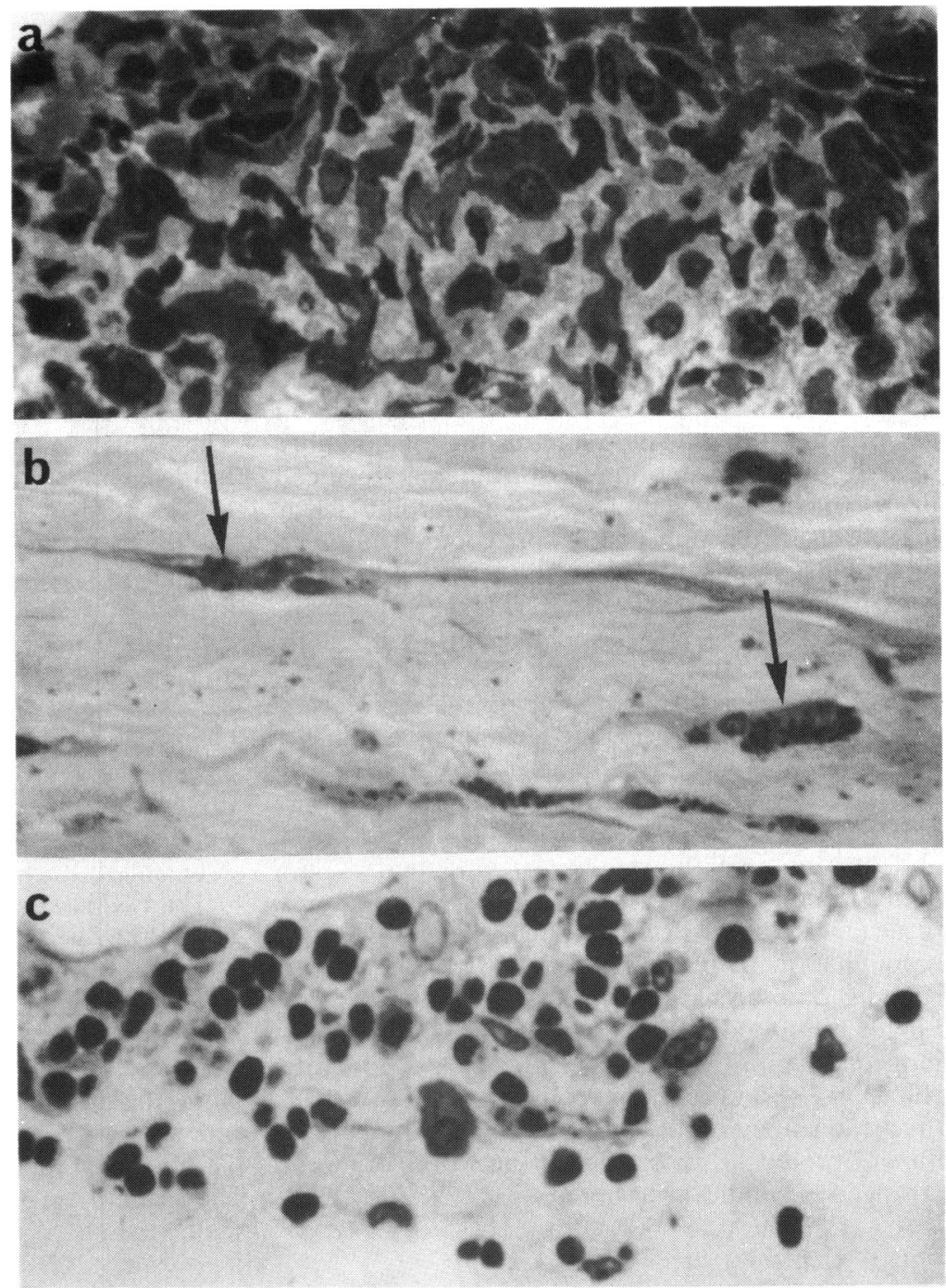

gates of cells of similar derivation within those 14 ERMs studied immunohistochemically for actin and FN; scattered and isolated cells were excluded from the analysis. Specific antibody labelling of glial fibrillary acidic protein (GFAP) identified an aggregate of glial cells in each of 12 ERMs'; and antiprekeratin immunostaining revealed an aggregate of epithelial cells (presumed to be of pigment epithelial cell origin) in seven ERMs ${ }^{211}$; and aggregates of fibroblast-like cells showing negative immunostraining for glial and epithelial cells (hereafter called 'fibroblasts') were available for study in 13 ERMs. Comparison of actin and FN staining intensities in all three types of cellular aggregate (glial cells, epithelial cells, and fibroblasts) was possible in six ERMs. In a further six ERMs two types of cellular aggregate were available for comparison, while in the two remaining ERMs only fibroblast aggregates were present.

\section{Results}

LIGHT MICROSCOPY AND CELL COUNTING

The mean total cell nucleus count per unit area ( \pm standard deviation) in the 21 early ERMs (Fig. 1a) was $16 \cdot 6 \pm 7 \cdot 2$; by contrast, the 24 late ERMs (Fig. 1b) had a mean of $9 \cdot 5 \pm 5 \cdot 8$, and the difference was significant (student's t test, $p<0 \cdot 001$; Table 1). Of the ERMs associated with rhegmatogenous retinal detachment, the mean total cell count in early ERMs (13 specimens) was $18.7 \pm 7.7$ and in late ERMs (7 specimens) was $9 \cdot 3 \pm 4 \cdot 2$ (student's t test, $\mathrm{p}<0 \cdot 01$ ). 
Table 1 Clinical details and quantitative results of 45 ERMs

\begin{tabular}{|c|c|c|c|c|c|c|c|c|}
\hline & \multirow[t]{2}{*}{ Aetiology } & \multirow{2}{*}{$\begin{array}{l}\text { No. of } \\
\text { ERMs }\end{array}$} & \multicolumn{2}{|c|}{ Cell counts per unit area $\pm S D$} & \multicolumn{4}{|l|}{ Collagen } \\
\hline & & & Total & Non-inflammatory & + & ++ & +++ & Bundles \\
\hline $\begin{array}{l}\text { Early } \\
\text { epimacular } \\
\text { membranes (11) }\end{array}$ & $\begin{array}{l}\text { RRD } \\
\text { Other* }\end{array}$ & $\begin{array}{l}4 \\
7\end{array}$ & $\begin{array}{l}18 \cdot 9 \pm 12 \cdot 3 \\
12 \cdot 8 \pm 5 \cdot 5\end{array}$ & $\begin{array}{l}17 \cdot 6 \pm 12 \cdot 6 \\
11 \cdot 2 \pm 5 \cdot 2\end{array}$ & $\begin{array}{l}2 \\
3\end{array}$ & $\begin{array}{l}2 \\
4\end{array}$ & $\begin{array}{l}0 \\
0\end{array}$ & $\begin{array}{l}1 \\
4\end{array}$ \\
\hline $\begin{array}{l}\text { Early MPP } \\
\text { membranes (10) }\end{array}$ & $\begin{array}{l}\text { RRD } \\
\text { Other* }\end{array}$ & $\begin{array}{l}9 \\
1\end{array}$ & $\begin{array}{l}18 \cdot 5 \pm 5 \cdot 7 \\
17 \cdot 0\end{array}$ & $\begin{array}{l}16 \cdot 5 \pm 5 \cdot 7 \\
15 \cdot 7\end{array}$ & $\begin{array}{l}9 \\
1\end{array}$ & $\begin{array}{l}0 \\
0\end{array}$ & $\begin{array}{l}0 \\
0\end{array}$ & $\begin{array}{l}2 \\
0\end{array}$ \\
\hline Total & & 21 & $16 \cdot 6 \pm 7 \cdot 2$ & $15 \cdot 1 \pm 7 \cdot 3$ & $15(72 \%)$ & $6(28 \%)$ & 0 & $7(33 \%)$ \\
\hline $\begin{array}{l}\text { Late } \\
\text { epimacular } \\
\text { membranes (19) }\end{array}$ & $\begin{array}{l}\text { RRD } \\
\text { Other* }\end{array}$ & $\begin{array}{r}6 \\
13\end{array}$ & $\begin{array}{r}8 \cdot 7 \pm 4 \cdot 1 \\
10 \cdot 4 \pm 7 \cdot 2\end{array}$ & $\begin{array}{l}7 \cdot 3 \pm 4 \cdot 1 \\
6 \cdot 6 \pm 2 \cdot 7\end{array}$ & $\begin{array}{l}1 \\
1\end{array}$ & $\begin{array}{l}3 \\
8\end{array}$ & $\begin{array}{l}2 \\
4\end{array}$ & $\begin{array}{l}5 \\
8\end{array}$ \\
\hline $\begin{array}{l}\text { Late MPP } \\
\text { membranes (5) }\end{array}$ & $\begin{array}{l}\text { RRD } \\
\text { Other* }\end{array}$ & $\begin{array}{l}1 \\
4\end{array}$ & $\begin{array}{l}13 \cdot 5 \\
7 \cdot 1 \pm 3 \cdot 1\end{array}$ & $\begin{array}{l}12 \cdot 6 \\
5 \cdot 4 \pm 2 \cdot 7\end{array}$ & $\begin{array}{l}1 \\
0\end{array}$ & $\begin{array}{l}0 \\
2\end{array}$ & $\begin{array}{l}0 \\
2\end{array}$ & $\begin{array}{l}1 \\
4\end{array}$ \\
\hline Total & & 24 & $9 \cdot 5 \pm 5 \cdot 8$ & $7 \cdot 1 \pm 2 \cdot 9$ & $3(13 \%)$ & $13(54 \%)$ & $8(33 \%)$ & $18(75 \%)$ \\
\hline
\end{tabular}

$\mathrm{MPP}=$ massive periretinal proliferation. $\mathrm{RRD}=$ rhegmatogenous retinal detachment. $\mathrm{SD}=$ standard deviation.

*Other aetiological associations: Perforating trauma: 3 early: 7 late (5 epimacular: 5 MPP)

Blunt trauma: $\quad 0$ early: 1 late (epimacular)

Idiopathic: 2 early: 1 late (epimacular)

Pars planitis: $\quad 1$ early: 3 late (epimacular)

Nodular telangiectasis ${ }^{21}: 0$ early: 3 late (epimacular)

Eales disease: 1 early: 1 late (epimacular)

Cone dystrophy: 1 early: 0 late (epimacular)

Branch vein occlusions: 0 early: 1 late (epimacular)

$+++=$ Abundant collagen.$++=$ Moderate collagen.$+=$ Minimal collagen .

Inflammatory cells were present in all ERMs, but their numbers showed considerable variation between individual specimens; they were most prominent in ERMs complicating pars planitis (Fig. 1c). Late ERMs contained proportionally more inflammatory cells (mean $21.6 \pm 20.0 \%$ ) than early ERMs (mean $11.5 \pm 5 \cdot 7 \%$ ). However, the standard deviations are particularly high, and thus there was no significant difference between the two groups (Mann-Whitney $U$ test). When inflammatory cells were excluded, the mean count for the 21 early ERMs was $15 \cdot 1 \pm 7 \cdot 3$ and for the 24 late ERMs $7 \cdot 9 \pm 2.9$ (student's t test, p<0.001). Degenerated (Fig. 1b) and necrotic cells represented $24 \cdot 8 \pm 14 \cdot 2 \%$ of the total non-inflammatory cells in early ERMs and $29 \cdot 8 \pm 16 \cdot 8 \%$ in late membranes.

Fifteen of the 21 early ERMs (72\%) contained minimal amounts of collagen, and in none of the other six early ERMs was collagen abundant. By contrast, only three of the 24 late ERMs $(13 \%)$ had a minimal collagen content, while eight late ERMs (33\%) contained abundant collagen. Bundles of collagen were seen in seven early ERMs (33\%) and 18 late ERMs (75\%) (Table 1).

CLINICOPATHOLOGICAL CORRELATION OF THE 23 SERIALLY GRADED EPIMACULAR MEMBRANES

Spearman Rank testing (Table 2) demonstrated that there was no correlation between the clinical opacification of our ERMs and either the collagen content or cellularity of the specimens. However, the test confirmed an inverse relationship between collagen content and cellularity $(p<0.01)$, as would be expected from our other quantitative results. The total cell count correlated positively with the total non-inflammatory $(p<0 \cdot 01)$ and the total inflam-

Table 2 Spearman rank correlation matrix for 23 serially graded epimacular membranes

\begin{tabular}{|c|c|c|c|c|}
\hline Variables & Collagen & $\begin{array}{l}\text { Total } \\
\text { cells }\end{array}$ & $\begin{array}{l}\text { Inflammatory } \\
\text { cells }\end{array}$ & $\begin{array}{l}\text { Non-inflammatory } \\
\text { cells }\end{array}$ \\
\hline $\begin{array}{l}\text { Opacity } \\
\text { Collagen } \\
\text { Total cells } \\
\text { Inflammatory cells } \\
\text { Non-inflammatory cells }\end{array}$ & $-0 \cdot 3271$ & $\begin{array}{c}0 \cdot 1567 \\
-0 \cdot 6600^{*}\end{array}$ & $\begin{array}{c}0.1860 \\
-0.4440 \\
0.7626^{*}\end{array}$ & $\begin{array}{r}-0.0969 \\
-0.6543^{*} \\
0.8136^{*} \\
0.4284\end{array}$ \\
\hline
\end{tabular}

*Significant at or better than $\mathrm{p}<0 \cdot 01$. 
Table 3 Proline and glucosamine autoradiography

\begin{tabular}{|c|c|c|c|c|}
\hline $\begin{array}{l}P / G \\
\text { (Figure) }\end{array}$ & $M P / M P P$ & Aetiology & $\begin{array}{l}\text { Approximate } \\
\text { ERM duration } \\
\text { (months) }\end{array}$ & $\begin{array}{l}\text { Overall avidity } \\
\text { of label } \\
\text { incorporation }\end{array}$ \\
\hline$P-3 a$ & MPP & RRD & 1 & - \\
\hline$P-3 b$ & MP & BT & $3 \cdot 5$ & + \\
\hline$P-3 c$ & MP & PT & $3 \cdot 5$ & + \\
\hline$P-3 d$ & MPP & RRD & 4 & +++ \\
\hline$P-3 e$ & MP & RRD & $4 \cdot 5$ & ++ \\
\hline$P-3 f$ & MPP & RRD & 6 & ++ \\
\hline$P-3 g$ & MP & RRD & 8 & + \\
\hline$G-4 a$ & MPP & PT & 3 & ++ \\
\hline$G-4 b$ & MPP & RRD & $3 \cdot 5$ & + to ++ \\
\hline$G-4 c$ & MP & RRD & 4 & + to ++ \\
\hline$G-4 d$ & MP & ROP/RRD & $4 \cdot 5$ & - \\
\hline$G-4 e$ & MPP & RRD & 8 & ++ \\
\hline
\end{tabular}

*Blood vessels show glucosamine uptake by endothelial cells.

$\mathrm{MP}=$ Macular pucker. $\mathrm{MPP}=$ Massive perirctinal proliferation. $\mathrm{RRD}=$ rhegmatogenous retinal detachment. $\mathrm{BT}=$ blunt trauma.

$\mathrm{PT}=$ perforating trauma. $\mathrm{ROP}=$ retinopathy of prematurity. $\mathrm{NCP}=$ no cells present. $I L L=$ inner limiting lamina. $\mathrm{P}=$ proline.

$\mathbf{G}=$ glucosaminc.

matory $(\mathrm{p}<0 \cdot 01)$ cell count respectively, because the total cell count comprised the latter two cell subsets.

THYMIDINE AUTORADIOGRAPHY

Three of the four early ERMs contained cells which incorporated labelled thymidine in organ culture (Fig. 2). By contrast only one of the 10 late ERMs contained cells which took up ${ }^{3} \mathrm{H}$ thymidine. In all four specimens which incorporated ${ }^{3} \mathrm{H}$ thymidine labelled cells were distributed throughout the tissue, and fewer than $5 \%$ of the total cells present were found to be labelled.

PROLINE AUTORADIOGRAPHY

Although all ERMs incubated with ${ }^{3} \mathrm{H}$ proline contained cells which incorporated the label, there was
Fig. 2 'H thymidine autoradiographic section I $\mu \mathrm{m}$ thick, counterstained with toluidine blue. The early membrane is hypercellular, and four cell nuclei are seen to have incorporated the label (arrows). (×280).

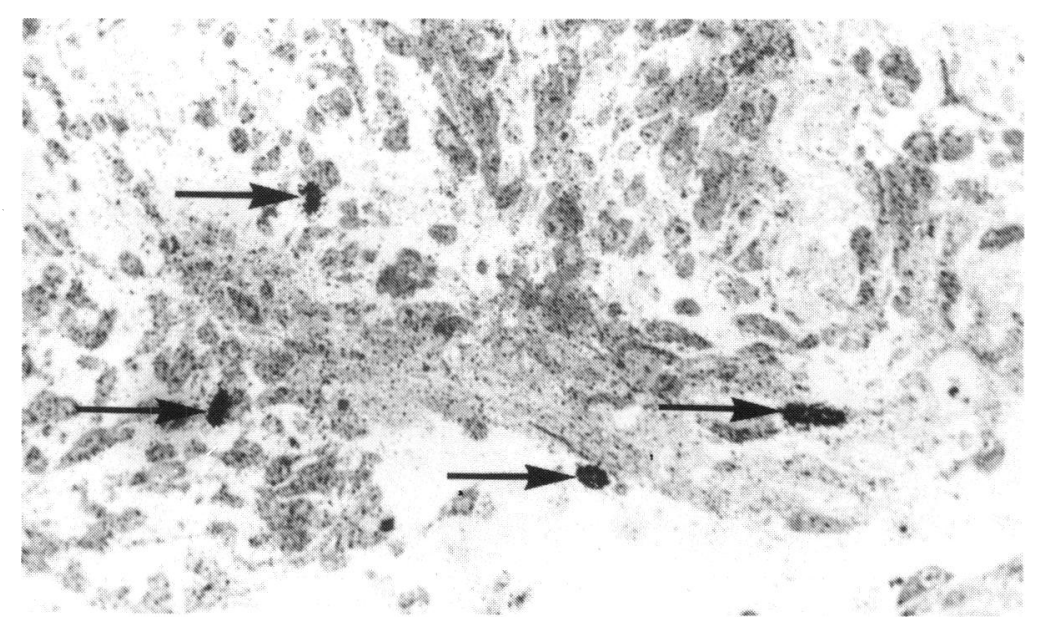




\begin{tabular}{|c|c|c|c|}
\hline $\begin{array}{l}\text { Overall } \\
\text { distribution } \\
\text { of label }\end{array}$ & $\begin{array}{l}\text { Avidity of incor- } \\
\text { poration of label } \\
\text { by spindle cells }\end{array}$ & $\begin{array}{l}\text { Avidity of incor- } \\
\text { poration of label } \\
\text { by cuboidal cells }\end{array}$ & Histological description and comment \\
\hline Patchy & - & - to + & $\begin{array}{l}\text { Hypercellular ERM, chicfly spindle cells } \\
\text { on ILL with little collagen }\end{array}$ \\
\hline Patchy & - to ++ & - to ++ & $\begin{array}{l}\text { Hypercellular ERM with spindle cells in } \\
\text { collagen and layers of cuboidal cells }\end{array}$ \\
\hline Patchy & + to ++ & + to +++ & $\begin{array}{l}\text { Hypocellular, collagenous ERM; spindle } \\
\text { cells predominate }\end{array}$ \\
\hline Uniform & +++ & NCP & $\begin{array}{l}\text { Hypercellular ERM of spindle cells in } \\
\text { collagen on ILL }\end{array}$ \\
\hline Patchy & ++ to +++ & +++ & $\begin{array}{l}\text { Collagenous ERM with prominent spindle and } \\
\text { cuboidal cell element }\end{array}$ \\
\hline Patchy & - & + to ++ & $\begin{array}{l}\text { Collagenous ERM with cuboidal cells } \\
\text { predominating over spindle cells }\end{array}$ \\
\hline Patchy & - to +++ & +++ & $\begin{array}{l}\text { Spindle and inflammatory cells on collagen. } \\
\text { Few cuboidal cells on ILL }\end{array}$ \\
\hline Patchy & - to ++ & ++ to +++ & $\begin{array}{l}\text { Hypercellular ERM with prominent spindle } \\
\text { cells and large focus of cuboidal cells }\end{array}$ \\
\hline Patchy* & + to ++ & - to ++ & $\begin{array}{l}\text { Cellular, little collagen and occasional } \\
\text { blood vessels }\end{array}$ \\
\hline Patchy & - to ++ & + to ++ & $\begin{array}{l}\text { Hypercellular, mainly spindle cell, ERM } \\
\text { with layer of cuboidal cells }\end{array}$ \\
\hline Patchy* & - to + & NCP & $\begin{array}{l}\text { Hypocellular, collagenous ERM with } \\
\text { occasional spindle cell and blood vessels }\end{array}$ \\
\hline Patchy & - & + to ++ & $\begin{array}{l}\text { Collagenous ERM, but many cuboidal, } \\
\text { spindle, and inflammatory cells }\end{array}$ \\
\hline
\end{tabular}

$+++=$ Intense labelling.

$++=$ Moderate labelling.

$+\quad=$ Weak labelling.

- $\quad$ = Background labelling.

considerable variation in the overall intensity of cell labelling both between and within membranes (Table 3 and Fig. 3). The results suggest that very early (Figs. $3 \mathrm{a}-\mathrm{c}$ ) and very late ERMs (Fig. 3g) did not incorporate as much ${ }^{3} \mathrm{H}$ proline as do 'middle age' (Figs. 3d-f) specimens. However, our series is too small to draw any firm conclusion about the ERM age and ${ }^{3} \mathrm{H}$ proline uptake. Inflammatory cells showed only minimal ${ }^{3} \mathrm{H}$ proline incorporation. By contrast both elongated spindle-shaped cells and plump (cuboidal) cells with prominent cytoplasm and large palestaining nuclei incorporated the label to varying degrees (Fig. 3). Where both cell types were present in an individual membrane, cuboidal cells appeared to take up ${ }^{3} \mathrm{H}$ proline more avidly than spindleshaped cells. This observation held true for cuboidal cells both within layers and foci or as scattered cells in collagen. Also notable was the great variation in ${ }^{3} \mathrm{H}$ proline uptake between cells of a similar morphological appearance within individual ERMs. This variation did not appear to be due to defects in label penetration of the specimens, since ${ }^{3} \mathrm{H}$ proline incorporation was found in cells at all depths of the tissues.

\section{GLUCOSAMINE AUTORADIOGRAPHY}

No obvious association between ${ }^{3} \mathrm{H}$ glucosamine uptake by specimens and ERM duration was observed (Table 3 and Fig. 4). There was, however, considerable variation in label incorporation in morphologically different cells. Overall, inflammatory cells showed minimal incorporation of ${ }^{3} \mathrm{H}$ glucosamine and spindle-shaped cells showed less avid incorporation than cuboidal cells, especially where the latter were arranged in layers (Fig. 4a). Two of our ERMs had a minor vascular component (Figs. 4b, 4d) and the endothelial cells of these vessels showed ${ }^{3} \mathrm{H}$ glucosamine uptake. Again, label penetration to all depths of the specimens was observed.

\section{IMMUNOHISTOCHEMISTRY FOR ACTIN AND FIBRONECTIN \\ Early vs. late ERMs}

Table 4 shows that in both early and late ERMs, intense actin staining was not prominent (Fig. 5a). There was no substantial difference in overall staining intensity for actin between cells in early and late ERMs (Table 4). Actin staining at greater than background levels was restricted to patches of cells in eight ERMs but was evenly distributed throughout the cells in three ERMs. In the remaining three late ERMs obvious staining was present only within small 

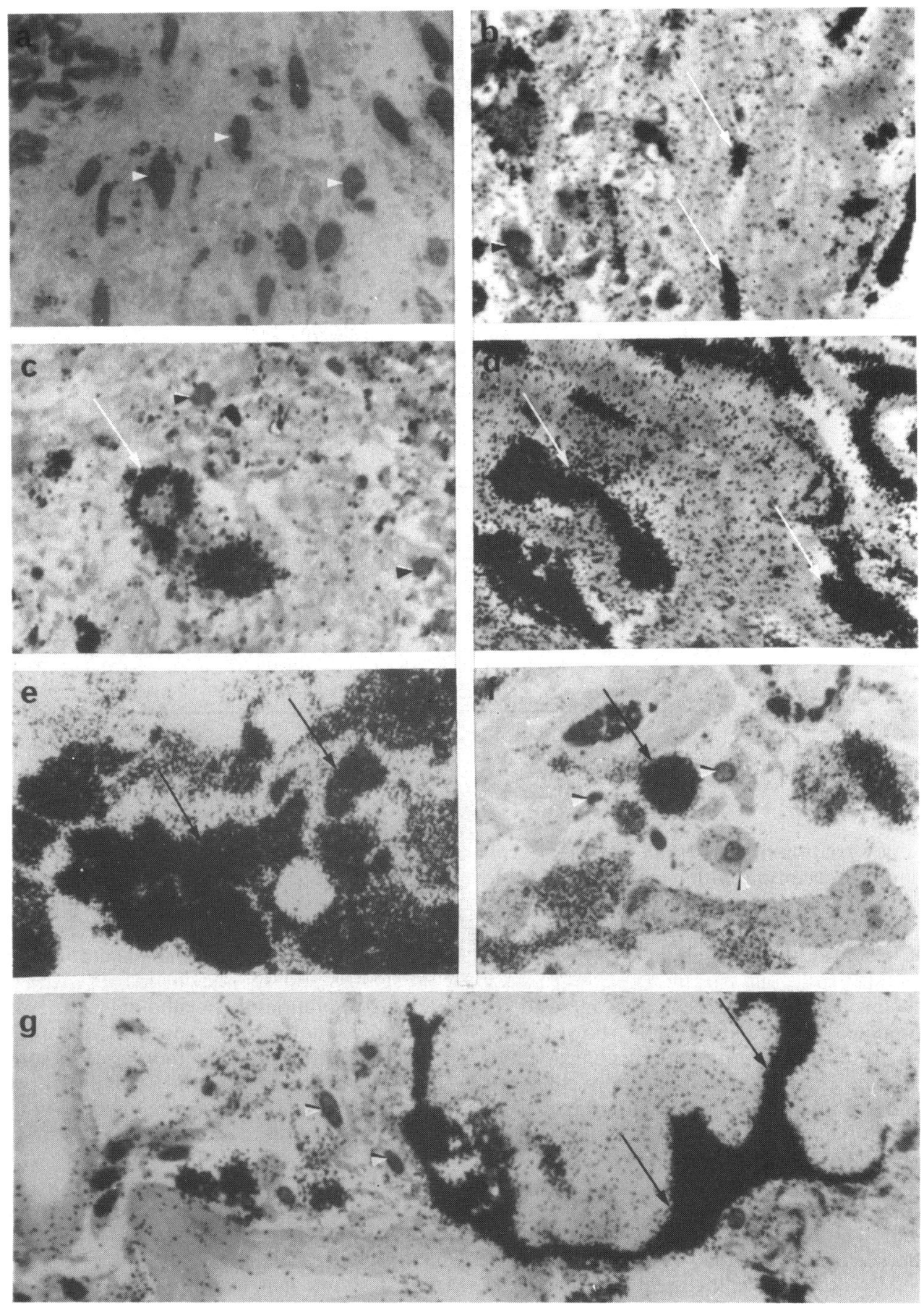

Fig. $3{ }^{3}$ H proline autoradiographic sections $1 \mu$ m thick, counterstained with toluidine blue. The photomicrographs are in order of ERM duration (see Table 2). The micrographs do not show representative areas of each ERM but demonstrate the variation in ${ }^{3} \mathrm{H}$ proline uptake between cells (arrows indicate cells incorporating label; arrowheads indicate nuclei of cells). (a) Some scattered cells, as evidenced by their nuclei, with background incorporation of ${ }^{3} \mathrm{H}$ proline; (b) some scattered cells show pronounced uptake of label; (c) two large cuboidal cells incorporating ${ }^{3} \mathrm{H}$ proline surrounded by cells which are not; (d) and (e) respectively show spindle and cuboidal cells which are so intensely labelled that the nuclei cannot be seen; (f) some cuboidal cells show maximal uptake, while others exhibit nearly background levels of incorporation; $(\mathrm{g})$ a late ERM with a layer of cells in which uptake of label is so intense that individual cell elements cannot be distinguished from each other. $(\times 700)$. 

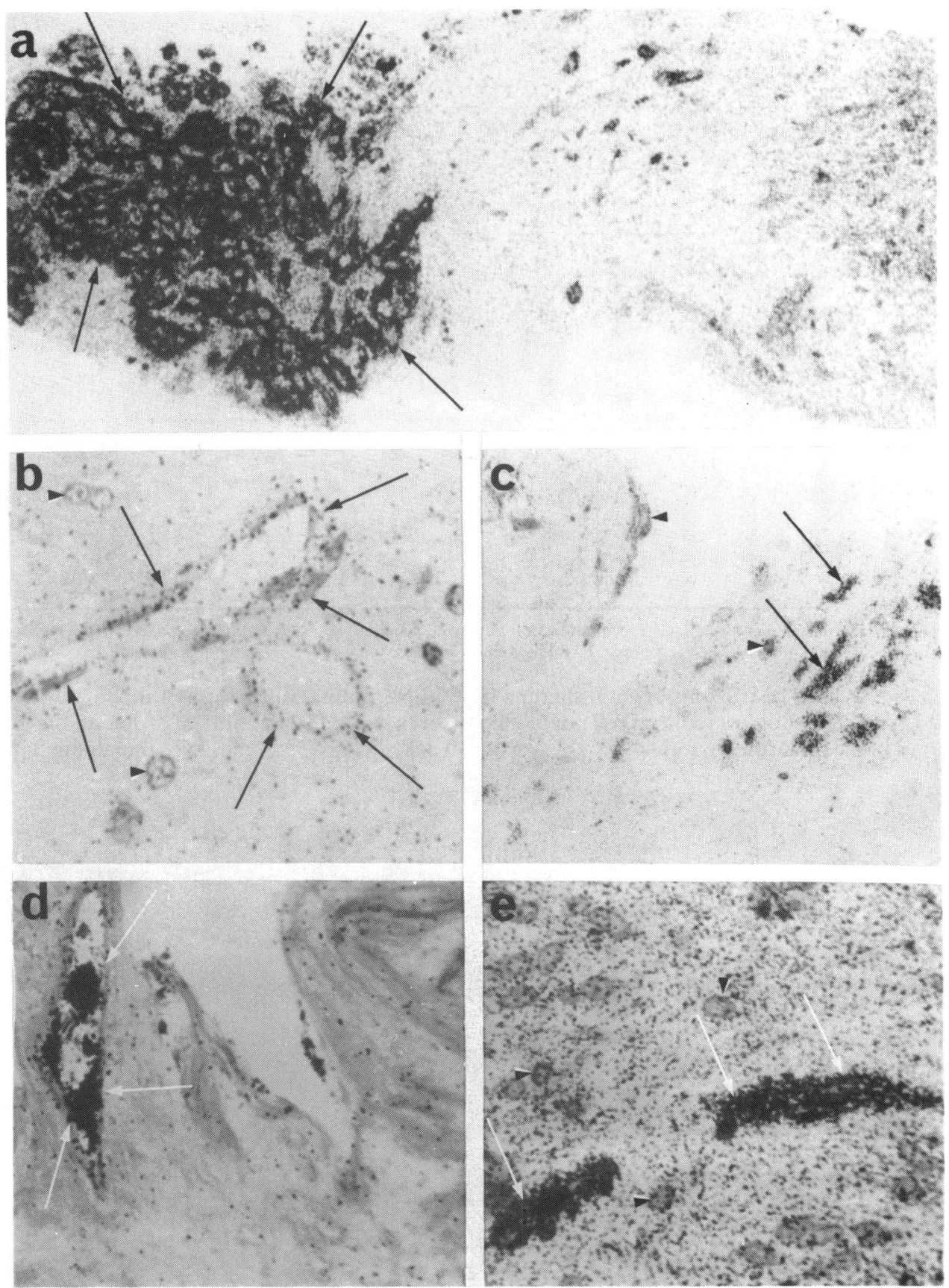

Fig. $4{ }^{3}$ Hglucosamine autoradiographic sections $1 \mu \mathrm{m}$ thick, counterstained with toluidine blue. The photomicrographs are focused on the silver grains and are in order of ERM duration (see Table 3). The micrographs do not show representative areas of each ERM, but demonstrate that cuboidal cells tend to show more avid label incorporation than spindle cells (arrows indicate cells incorporating label; arrowheads indicate nuclei of cells). (a) A coiled layer of cuboidal cells show intense incorporation of label, while spindle cells in the rest of the specimen show background labelling; (b) and (d) endothelial cells of blood vessels in two ERMs demonstrate weak and intense labelling respectively; (c) there is variation from background to moderate ${ }^{3} \mathrm{H}$ glucosamine uptake between cell types in this ERM; (e) some cuboidal cells show avid ${ }^{3} \mathrm{H}$ glucosamine uptake, while others only show background incorporation. $(a, c, \times 350 ; b, d, e$, $\times 700$ ). 
Table 4 Immunohistochemistry of 14 ERMs

\begin{tabular}{|c|c|c|c|c|c|c|c|}
\hline & \multirow[t]{2}{*}{ No. } & \multirow[t]{2}{*}{ Aetiology } & \multirow[t]{2}{*}{$F / P$} & \multicolumn{4}{|l|}{ Actin } \\
\hline & & & & Distribution & $\begin{array}{l}\text { Overall } \\
\text { staining } \\
\text { intensity }\end{array}$ & $\begin{array}{l}\text { Intensity } \\
\text { in glial } \\
\text { aggregates }\end{array}$ & $\begin{array}{l}\text { Intensity in } \\
\text { epithelial } \\
\text { aggregates }\end{array}$ \\
\hline \multirow{5}{*}{$\begin{array}{l}\text { Early } \\
\text { epimacular } \\
\text { membranes (4) }\end{array}$} & & & & & & & \\
\hline & 1 & RRD & $\mathbf{P}$ & Even & $+t$ & NAP & NAP \\
\hline & 2 & RRD & $\mathbf{P}$ & Even & ++ & ++ & NAP \\
\hline & 3 & RRD & $\mathbf{F}$ & Patchy & ++ & - & ++ \\
\hline & -4 & RRD & $\mathbf{P}$ & Patchy & ++ & - & NAP \\
\hline \multirow{3}{*}{$\begin{array}{l}\text { Early MMP } \\
\text { membranes (3) }\end{array}$} & 5 & RRD & $\mathbf{F}$ & Patchy & ++ & + & + \\
\hline & 6 & RRD & $\mathbf{P}$ & Patchy & ++ & NAP & NAP \\
\hline & 7 & PT & $\mathbf{P}$ & Patchy & ++ & $\cdot++$ & NAP \\
\hline \multirow{5}{*}{$\begin{array}{l}\text { Late } \\
\text { epimacular } \\
\text { membranes (4) }\end{array}$} & & & & & & & \\
\hline & 8 & RRD & $\mathbf{P}$ & Even & ++ & ++ & +++ \\
\hline & 9 & RRD & $\mathbf{P}$ & Patchy & ++ & + & ++ \\
\hline & 10 & PT & $\mathbf{F}$ & Small foci & ++ & + & NAP \\
\hline & 11 & RS & $\mathbf{P}$ & Small foci & + & - & NAP \\
\hline \multirow{3}{*}{$\begin{array}{l}\text { Late MPP } \\
\text { membranes (3) }\end{array}$} & 12 & RRD & $\mathbf{F}$ & Patchy & ++ & ++ & ++ \\
\hline & 13 & RRD & $\mathbf{P}$ & Small foci & + & + & + \\
\hline & 14 & BT & $\mathbf{P}$ & Patchy & ++ & - & +++ \\
\hline
\end{tabular}

$\mathrm{MPP}=$ massive periretinal proliferation. $\mathrm{RRD}=$ rhegmatogenous retinal detachment $. \mathrm{PT}=$ perforating trauma $. \mathrm{BT}=$ blunt trauma . $\mathrm{RS}=$ retinoschisis. $\mathrm{P}=$ immunoperoxidase technique. $\mathrm{F}=$ immunofluorescent technique. $\mathrm{NAP}=$ no aggregate present .

foci of cells, but such restrictions of actin staining in late ERMs may reflect only a reduced cell population as reported in the quantitative series.
FN staining was intense or moderate overall in all seven early ERMs and five out of the seven late ERMs (Fig. 5b); the two remaining late ERMs
Fig. 5 Dewaxed sequential $7 \mu \mathrm{m}$ sections from an early ERM.

(a) Immunoperoxidase stain for actin shows heterogeneous staining pattern from weak (arrowheads) to intense (arrows), while in

(b) immunoperoxidase staining for fibronectin shows more

homogenous distribution. Note the fibrillar arrangement of fibronectin (arrow). $(\times 140)$.

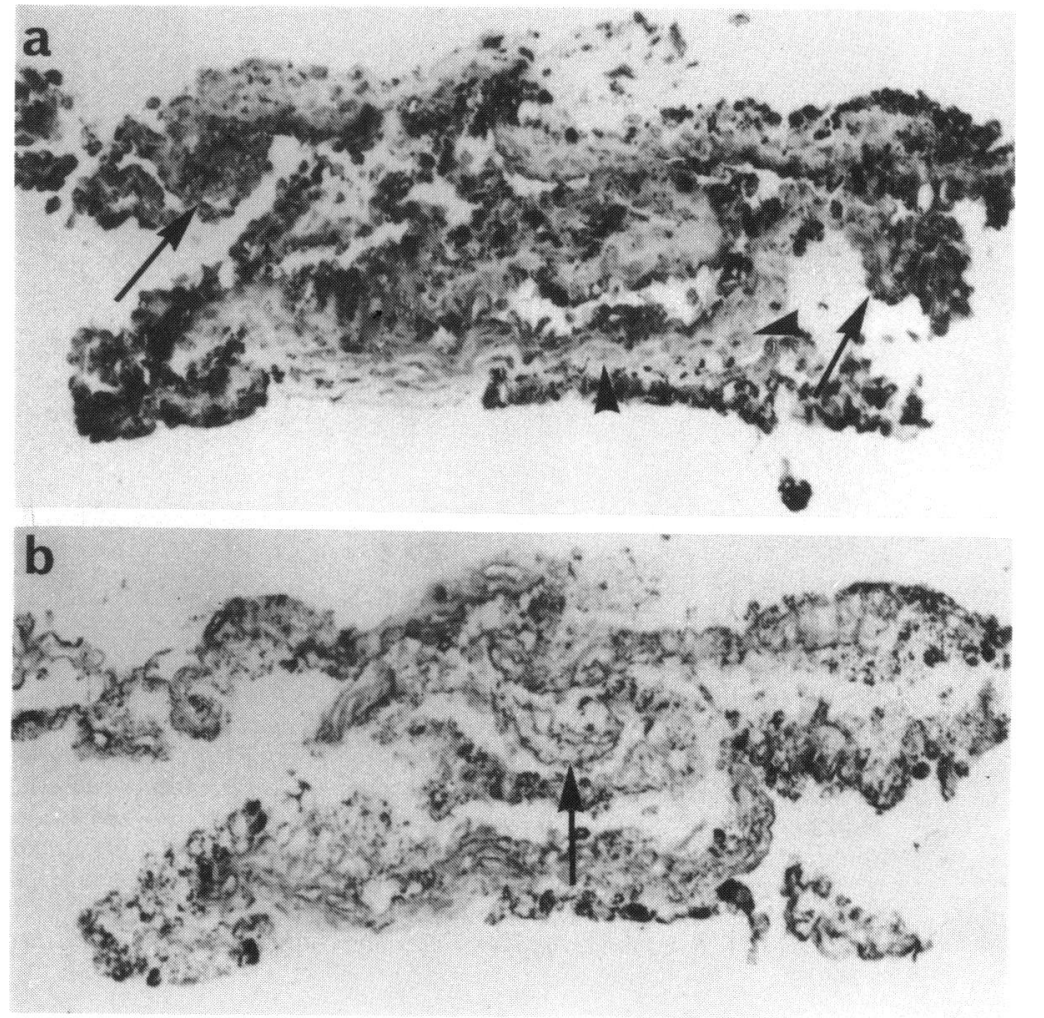




\begin{tabular}{|c|c|c|c|c|c|}
\hline \multirow[b]{2}{*}{$\begin{array}{l}\text { Intensity in } \\
\text { fibroblast } \\
\text { aggregates }\end{array}$} & \multicolumn{5}{|l|}{ Fibronectin } \\
\hline & Distribution & $\begin{array}{l}\text { Overall } \\
\text { staining } \\
\text { intensity }\end{array}$ & $\begin{array}{l}\text { Intensity } \\
\text { in glial } \\
\text { aggregates }\end{array}$ & $\begin{array}{l}\text { Intensity in } \\
\text { epithelial } \\
\text { aggregates }\end{array}$ & $\begin{array}{l}\text { Intensity in } \\
\text { fibroblast } \\
\text { aggregates }\end{array}$ \\
\hline++ & Even & ++ & NAP & NAP & ++ \\
\hline++ & Even & ++ & ++ & NAP & ++ \\
\hline++ & Patchy & +++ & +++ & +++ & +++ \\
\hline++ & Patchy & ++ & + & NAP & +++ \\
\hline++ & Patchy & +++ & +++ & +++ & +++ \\
\hline++ & Even & +++ & NAP & NAP & +++ \\
\hline+++ & Patchy & +++ & +++ & NAP & +++ \\
\hline NAP & Patchy & ++ & ++ & ++ & NAP \\
\hline++ & Patchy & ++ & ++ & + & ++ \\
\hline++ & Patchy & $++t$ & +++ & NAP & +++ \\
\hline+ & Nil & - & - & NAP & - \\
\hline+++ & Patchy & ++ & ++ & ++ & $+t$ \\
\hline++ & Patchy & + & + & + & + \\
\hline+++ & Patchy & +++ & + & +++ & +++ \\
\hline
\end{tabular}

$++=$ Intense staining.

$+=$ Moderate staining.

$=$ Weak staining.

=Background staining.

showed nil or weak staining. Both intra- and extracellular FN was stained, and FN staining around clusters of cells was usually more intense than that in hypocellular collagenous areas of ERMs. The distribution of FN in ERMs was usually patchy, but in three early ERMs there was a more widespread (even) FN distribution. Thus there was a marginally apparent trend towards more abundant FN staining in early than in late ERMs, and this reflected the paucity of FN in mature collagen. Strips of inner limiting lamina (ILL), which were present in nine of the 14 ERM specimens, stained weakly for FN (except where the ILL was surmounted by cells, when more intense ILL staining was apparent).

\section{Specific cellular aggregates}

Despite some variation of actin staining within individual cell types in ERMs there was a clear-cut difference in actin staining between different cell types (Table 4). Glial cells (Fig. 6a) often stained poorly for actin (Fig. 6b), while fibroblast-like cells stained the most intensely. Epithelial cells, the least represented cell type in the 14 specimens, showed an actin staining level intermediate between glial and fibroblastic cells. An exception to this trend was the single ERM with a predominant epithelial component, which showed intense actin staining in some cytokeratin-positive aggregates (Fig. 7a, 7b).

Variable FN staining was seen within clusters of specific cell types, but no obvious trends emerged regarding FN staining intensity between different cell types (Table 4 and Fig. 6c).

\section{Discussion}

Analyses of precisely aged experimental and human granulation tissue have provided detailed information about the chronological sequence of events in wound healing..$^{37 \times}$ We recognise that investigations of postcontractile ERMs removed at inaccurately assessed times during their potentially disparate clinical courses cannot provide equivalent data on the natural history of human epiretinal proliferations. Nevertheless, arbitrary division of a large number of human ERM specimens into early and late groups (based on clinical history) has revealed trends which indicate that they have certain features in common with the later phase of wound healing. Late ERMs, for example, contained fewer cells but more abundant collagen than early membranes. The death and disintegration of fibroblasts entombed in collagen thus attests to the ultimate fate of many cells in ERMs, though our reported percentages $(25-30 \%)$ of necrotic cells may be spuriously high owing to surgical manipulation and removal of the ERMs. Nevertheless, we were impressed by the frequent persistence of layers of glial or epithelial cells adjacent to the fibrous component even in late ERMs (reminiscent of the surface epithelium over the healed scar in skin wounds). 
Fig. 6 Sequential $10 \mu m$ frozen sections from an ERM.

(a) Immunofluorescent stain for GFAP. Note there is a layer of positively staining cells (arrows), which are therefore glial, at the margin of a membrane which contains negative (non-glial) cells (askerisk). (b) Immunofluorescent stain for actin. The non-glial fibroblast-like cells stain moderately for actin, while glial cells are only weakly stained.

(c) Immunofluorescent stain for fibronectin. The glycoprotein can be seen to be present in both glial and non-glial components of the membrane. $(\times 560)$.
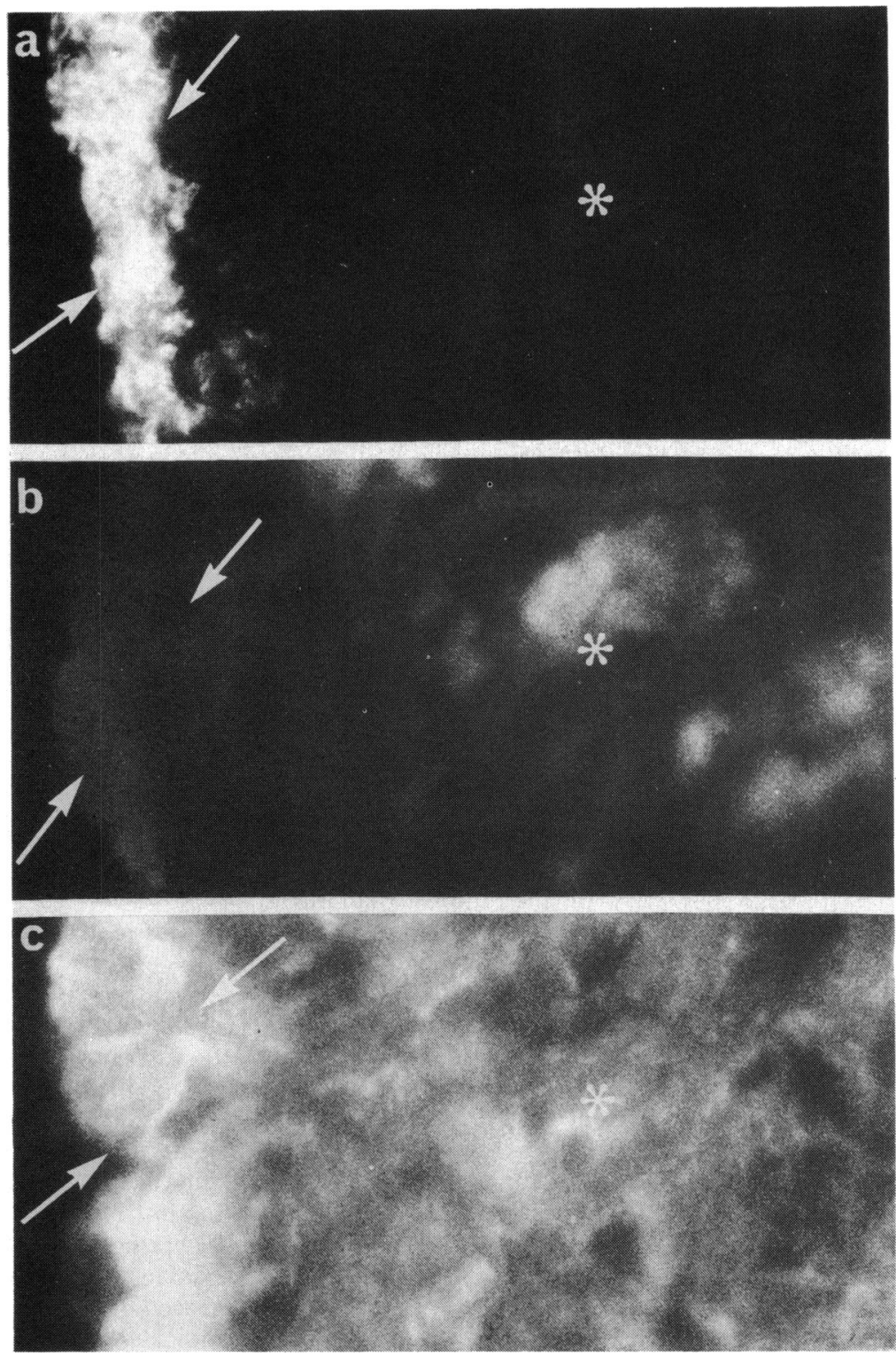

Trese, Chandler, and Machemer $^{22}$ recently reported a clear-cut correlation between the biomicroscopic opacification of ERMs and their collagen content on histopathological analysis. Such a correlation was not confirmed in this study; thin collagenous membranes were often transparent, while essentially cellular ERMs were sometimes opaque (especially those associated with ocular inflammation). This is not surprising when one considers that cellular or subcellular aggregates in an adjacent location to ERMs are also opaque-for example, vitreous snowballs and axoplasmic debris in 


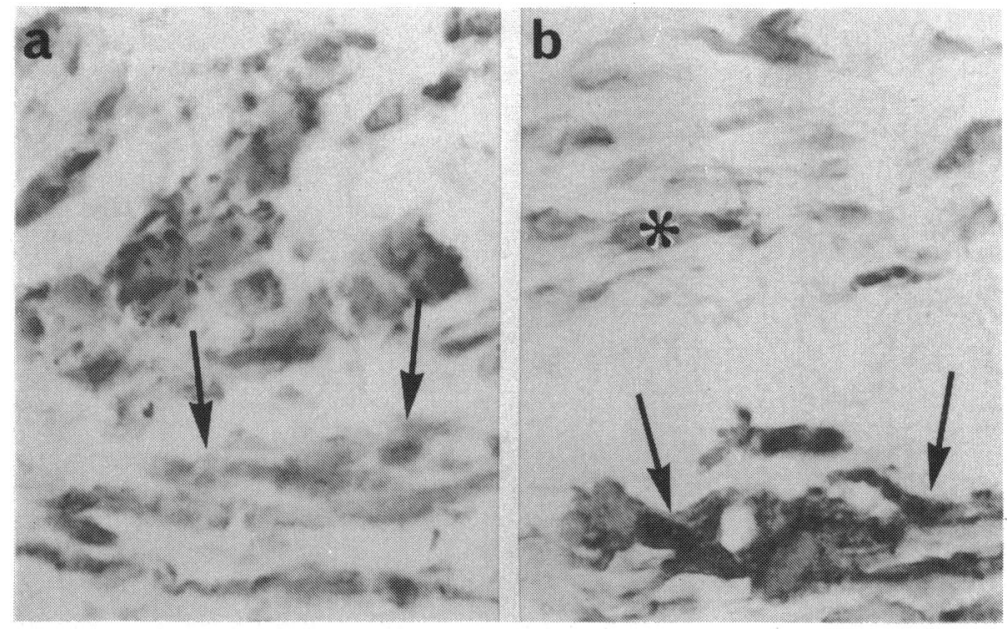

Fig. 7 Dewaxed $7 \mu$ m sections from an ERM containing spindle and cuboidal cells. Arrows show the same area at different depths into the tissue.

(a) Immunoperoxidase stain for keratin. The cells in the membrane show a positive reaction and are therefore of epithelial origin. (b) Immunoperoxidase stain for actin. The epithelial cells show variation in their staining characteristics. Those areas indicated by the asterisk have a moderate reaction, while those arrowed have an intense reaction. $(\times 560)$.

adhesion, cell-to-substratum adhesion, and subsequent cell-spreading. ${ }^{25-27}$ Thereafter $\mathrm{FN}$ is secreted by the fibroblasts themselves (along with procollagen) in an insoluble multimeric form to produce a fibrillar extracellular matrix which has important relationships across cell membranes with microfilament proteins such as actin. ${ }^{2 \times}{ }_{29}^{29}$ FN may also enhance phagocytosis of debris in wounds s $^{31}$ ('opsonic activity') but gradually disappears with maturation of collagen. ${ }^{3}$

FN was abundant in most of the ERMs studied immunohistochemically, being reduced in amount only among dense collagen bundles and being generally deficient in just two very late ERMs. The source of FN in ERMs is unclear, although many.of the constituent cell types (macrophages, glial cells, epithelial cells, and fibroblasts) are known to be capable of FN synthesis. It is likely that the multiple functions of FN as determined in wounds apply equally well to ERMs - for example, cell adhesion, phagocytosis, and transmembrane relationships with contractile proteins. FN was invarilably present at sites in ERMs where actin staining was prominent. Thus FN appears to be vital not only in stimulating and maintaining the integrity of ERMs but also in linking the contraction of fibroblasts or other actincontaining cells to produce a "contractile cohesive unit'.

Actin is a component of most ocular cells $\mathrm{s}^{31}$ and is especially prominent during the migratory and contractile phases of experimental vitreous membranes. ${ }^{32}$ The relative paucity of intense antiactin staining in the epiretinal cellular aggregates (and the scarcity of myofibroblasts) may reflect the postcontractile state of the biopsied ERMs. However, the pattern of actin staining in specific cell aggregates was in keeping with the concept that
ERM $^{1921}$ contraction is mediated by fibroblasts or epithelial cells (the former being the predominant cell type in most ERMs) and that glial cells do not have a major role in ERM contraction. ${ }^{19}{ }^{21}$

AN ANARCHISTIC SCAR

Despite the similarities between healing skin wounds and ERMs in terms of component cells and processes there are also striking differences, in particular the duration and sequence of cellular activities. In skin healing the initial cellular proliferation ${ }^{3}$ is restricted to a short, clear-cut wave of activity. FN is abundant at first but disappears from experimental dermal scars within five weeks ${ }^{+}$and from corneal wounds within seven days of injury. ${ }^{33}$ By contrast our thymidine autoradiographic results suggests that the capacity for cellular proliferation persists well into the postcontractile phase of ERM development, while proline and glucosamine were incorporated into late ERMs at levels which compared favourably with those of early ERMs. Similarly, FN was abundant in all but the most mature scars. Thus the activities of ERM cells appear to be very protracted, as they are in some visceral wounds, ${ }^{34}$ reflecting either unusual persistence of metabolically active subsets of cells or recruitment of additional cells to the ERM during its clinical course. Bearing in mind the absence of any blood supply to most fibrocellular ERMs (which in healing wounds is a key factor in maintaining the activities of cells), the second mechanism (that is, recruitment) appears the more likely, as is further supported by the variation in proline and glucosamine incorporation from cell to cell both within and between cell groups at any given time. Continuing cell recruitment may reflect a persistent stimulus, for example inflammation, and it is of interest that the two eyes in this series showing 

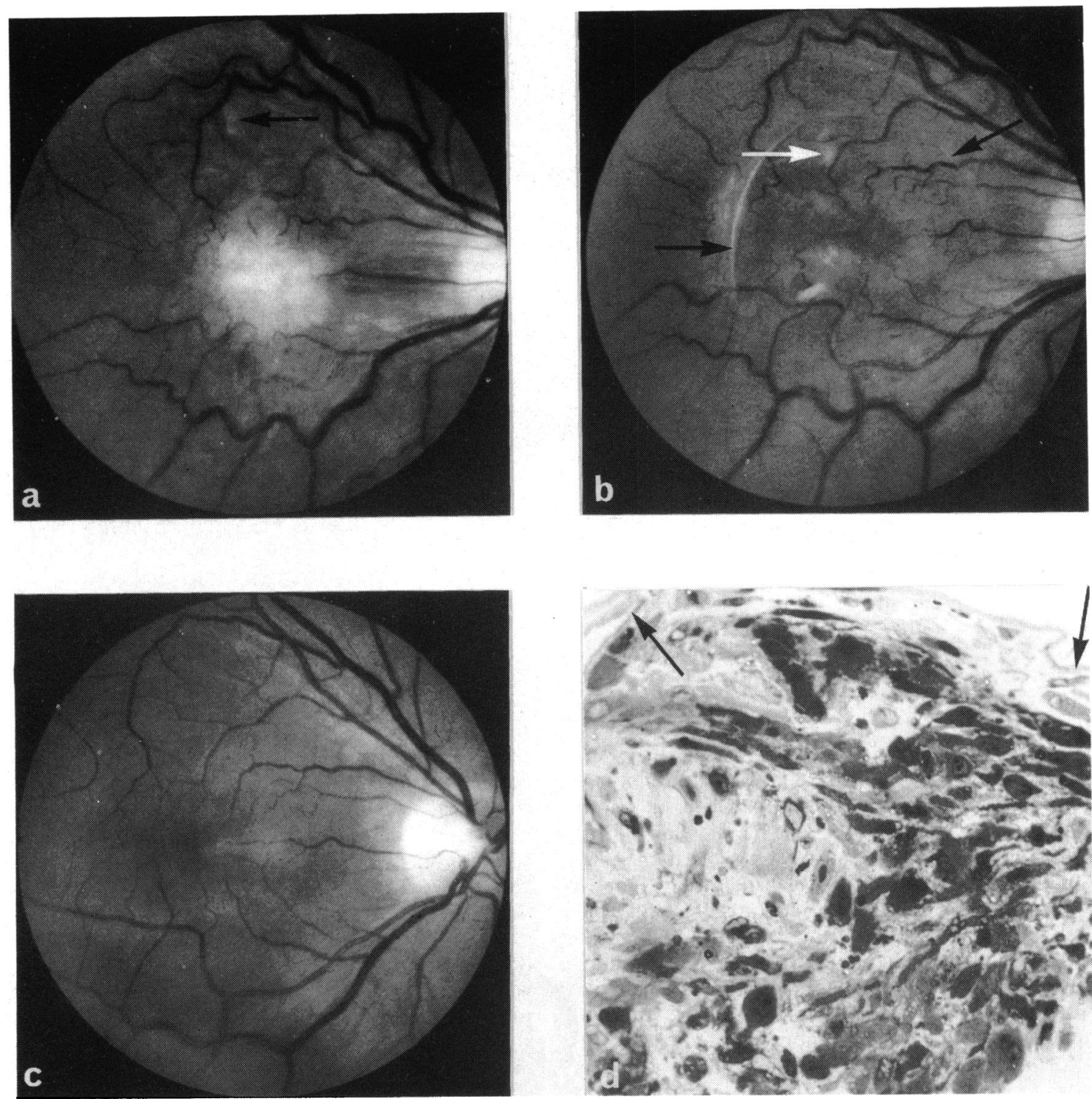

Fig. 8 Clinicopathological correlation. (a) Opaque idiopathic epimacular membrane of three months' clinical duration; outer retinal oedema (arrow) and tortuous vessels (acuity 5/60). (b) Three days after membrane dissection; circular edge of excised cortical gel and ILL (black arrows) and axoplasmic debris (white arrow). (c) Four months after membrane dissection; spontaneous detachment of residual gel and ILL, and restoration of course of major vessels (acuity 6/6). (d) Light microscopy of ERM specimen showing heterogeneous hypercellular membrane with bizarre cell forms attached to ILL (arrows); minimal collagen content. $(\times 250)$.

recurrent proliferation after epimacular membrane peeling had pars planitis.

What are the implications for treatment of these poorly regimented (or 'anarchistic') activities of ERMs as revealed in organ culture? Certainly persistent recruitment of cells into ERMs poses considerable problems in planning treatment regimens by antiproliferative agents such as 5-fluorouracil. By contrast the disorderly behaviour of ERM cells probably underlies the abundance of FN seen at all stages of ERM development. Since experimental studies have shown that some of the effects mediated by this glycoprotein can be blocked ${ }^{2+26} \mathrm{FN}$ might represent a more opportune target at which drug or immune intervention could be aimed in the management of ERMs. 
We thank Mr RJ Cooling, Mr Z Gregor, Mr PK Leaver, and Mr AH Chignell, who provided many of the surgical specimens, and Mr G Nunn for ensuring their safe collection. Mr R Alexander, Mr J Prasad, and Mr K Schmi provided technical assistance. Mrs $P$ Goodwin, Miss M Baines, and Miss H Lucas provided secretarial help.

Our research has been funded by the TFC Frost Charity Trust, the Wellcome Trust (grant no. 10998/1.5), the Muirhead Settlement, the Moorfields Locally Organised Rescarch Scheme, the Moorficlds Endowment Fund, and the Help the Hospitals Charitable Trust.

\section{References}

1 Constable IJ, Tolentino FI, Donovan RH, Schepens CL. Clinico-pathologic correlation of vitreous membranes. In: Pructt RD, Regan DJ, eds. Retinal congress. New York: Appleton-Century-Crofts, 1974: 245-57.

2 Recser FH, Aaberg TM. Vitreous humour. In: Records RE, ed. Physiology of the human eye and visual system. Hagcrstown: Harper and Row, 1979: 261-95.

3 Peacock EE. Inflammation and the cellular response to injury. Wound repair. Philadelphia: Saunders, 1984: 1-14.

4 Kurkinen M, Vaheri A, Roberts PJ, Stenman S. Sequential appearance of fibronectin and collagen in experimental granulation tissuc. Lab Invest 1980: 43: 47-51.

5 Pcarlstein E, Gold LI, Garcia-Pardo A. Fibronectin: a review of its structure and biological activity. Mol Cell Biochem 1980; 29: 103-28.

6 Gabbiani G, Ryan GB, Majno G. Presence of modified fibroblasts in granulation tissue and their possible role in wound contraction. Experientia 1971; 15: 549-50.

7 Ryan GB, Cliff WJ, Gabbiani G, et al. Myofibroblasts in human granulation tissue. Hum Pathol 1974; 5: 55-67.

8 Ross R, Benditt EP. Wound healing and collagen formation. I. Sequential changes in the components of guinea pig skin wounds observed in the electron microscope. J Biophys Biochem Cytol 1961; 11: 677-700.

9 Ross R. The fibroblast and wound repair. Biol Rev 1968; 43: 51-96.

10 Machemer R, Van Horn D, Aaberg TM. Pigmented epithelial proliferation in human retinal detachment with massive periretinal proliferation. Am J Ophthalmol 1978; 85: 181-91.

11 Green WR, Kenyon KR, Michels RG, Gilbert HD, De La Cruz Z. Ultrastructure of epiretinal membranes causing macular pucker after retinal re-attachment surgery. Trans Ophthalmol Soc UK 1979; 99: 65-77.

12 Kampik A, Kenyon KR, Michels RG, Green WR, De La Cruz Z. Epiretinal and vitrcous membranes: comparative study of 56 cases. Arch Ophthalmol 1981; 99: 1445-54.

13 Michels RG. A clinical and histopathologic study of epiretinal membranes affecting the macular and removed by vitreous surgery. Trans Am Ophthalmol Soc 1982; 80: 580-656.

14 Rodrigues MM, Newsome DA, Machemer R. Further characterization of epiretinal membranes in human massive periretinal proliferation. Curr Eye Res 1981; 6: 311-5.

15 Wallow IHL, Greaser ML, Stevens TS. Actin filaments in diabetic fibrovascular preretinal membrane. Arch Ophthalmol 1981; 99: 2175-81.

16 Wallow IHL, Stevens TS, Greaser ML, Bindley C, Wilson R. Actin filaments in contracting preretinal membranes. Arch Ophthalmol 1984; 102: 1370-5.

17 Carter WG, Fukuda M, Lingwood C, Hakomori S. Part III. Characteristics of the high-molecular weight fibroblast surfaceassociated glycoprotein. Chemical composition, gross structure and organization of transformation-sensitive glycoproteins. Ann NY Acad Sci 1978; 312: 160-77.

18 Hiscott PS, Gricrson I, Hitchins CA, Rahi AHS, McLcod D. Epiretinal membranes in vitro. Trans Ophthalmol Soc UK 1983; 103: 89-102.

19 Hiscott PS, Gricrson I, Trombetta CJ, Rahi AHS, Marshall J, McLcod D. Retinal and epiretinal glial: an immunohistochemical study. BrJ Ophthalmol 1984; 68: 698-707.

20 Hiscott PS, Grierson I, McLeod D. Retinal pigment epithelial cells in epiretinal membranes: an immunohistochemical study. BrJ Ophthalmol 1984; 68: 708-15.

21 Baines PS, Hiscott PS, McLcod D. Posterior non-vascularised proliferative extraretinopathy and peripheral nodular retinal tclangicctasis. Trans Ophthalmol Soc UK 1982; 102: 487-91.

22 Trese M, Chandler DB, Machemer R. Macular pucker. II. Ultrastructurc. Graefes Arch Klin Exp Ophthalmol 1983; 221: 16-26.

23 McLeod D. Reappraisal of the retinal cotton-wool spot: a discussion paper. $J R$ Soc Med 1981; 74: 682-6.

24 Tsukamoto Y, Helsel WE, Wahl SM. Macrophage production of fibronectin a chemoattractant for fibroblasts. J Immunol 1981; 127: $673-8$.

25 D'Ardenne AJ, McGec JO'D. Fibronectin in discasc. J Pathol 1984: 142: 235-51.

26 Yamada KM, Yamada SS, Pastan I. The major cell surface glycoprotcin of chick cmbryo fibroblasts is an agglutinin. Proc Nat Acad Sci USA 1975; 72: 3158-62.

27 Nishida T, Nakagawa S, Ohashi Y, Awata T, Manabe R. Fibronectin in corneal wound healing: appearances in cultured rabbit cornea. Jpn J Ophthalmol 1982; 26: 410-5.

28 Hynes RO, Destree AT. Relationships between fibronectin (LETS protein) and actin. Cell 1978; 15: 875-86.

29 Heggeness MH, Ash JF, Singer SJ, Transmembrane linkage of fibroncctin to intracellular actin-containing filaments in cultures human fibroblasts. Ann NY Acad Sci 1978; 312: 414-7.

30 Grinnell F, Billingham RE, Burgess L. Distribution of fibronectin during wound healing in vivo. J Invest Dermatol 1981; 76: $181-9$

31 Rahi AHS, Gricrson I, Ashton N. Contractile proteins in ocular tissues: their role in health and diseasc. Trans Ophthalmol Soc UK 1980; 100: 155-61.

32 Gricrson I, Rahi AHS. Structural basis of contraction in vitreal fibrous membranes. Br J Ophthalmol 1981; 65: 737-49.

33 Suda T, Nishida T, Ohashi Y, Nakagawa S, Manabe R. Fibroncctin appears at the site of corneal stromal wounds in rabbits. Curr Eye Res 1981; 1: 553-6.

34 Peacock EE. Collagenolysis and the biochemistry of wound repair. Wound repair. Philadelphia: Saunders, 1984: 102-40. 